\title{
The Five Laws of Library Science from a Japanese Angle*
}

\author{
Dr. Satoru Takeuchi**
}

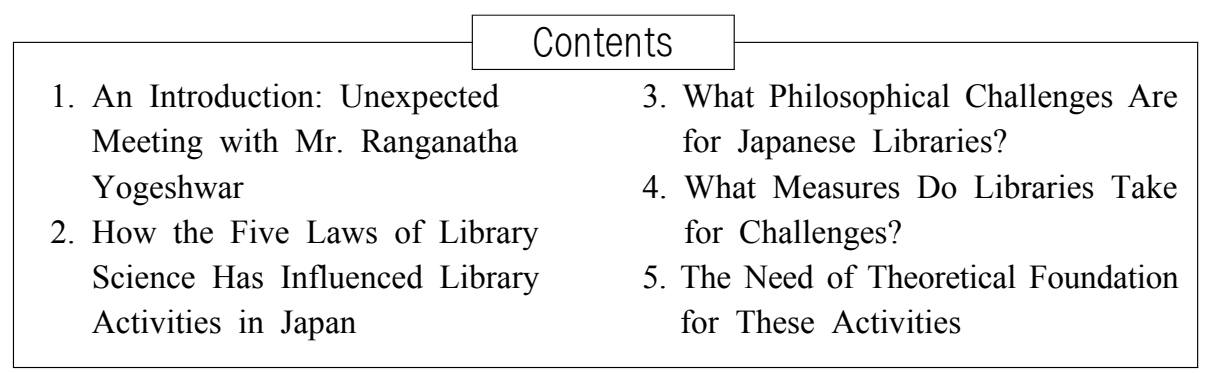

\begin{abstract}
The Five Laws of Library Science was introduced into Japan in 1935. After World War II, it was widely disseminated among young librarians by the education for librarianship developed in the 1950's. Its concept, "Books for All," met a serious opposition from local authorities based on their long continued concept of "preservation." After they realized that people eagerly use local libraries, they interpreted that the duty of public library was "lending books." They introduced "Privatization" of libraries into quite a few local libraries in order to save money.

For overcoming problems, it is important to disseminate the library concept among the public, the assembly members and government officials planning to change their attitude of disregarding libraries. As the fundamental library philosophy, the Five Laws of Library Science is important. In the commentary of the Five Laws written by the present writer, he included an illustration of triangle pyramid showing the structure of the Five Laws. He included here the spiral of study on the library and the library science, based on the Section 814 of the Five Laws. He welcomes discussions on his Japanese angle from different viewpoints in order to develop further understanding of the Five Laws.

Keywords: "Books for All" concept, Disregarding Libraries, Preservation, as a traditional concept, Privatization of library management, Spiral of studying the library and library science, Triangle pyramid on the structure of the Five Laws
\end{abstract}

* This article was originally presented at the International Seminar Commemorating the 80th Anniversary of Ranganathan's "Five Laws of Library Science," held in Daejon, Korea, 20 October 2011.

** Professor Emeritus, University of Library and Information Science, Japan

논문접수일자: 2011년 10월 4일 최초심사일자: 2011년 11월 4일 게재확정일자: 2011년 11월 27일 한국문헌정보학회지, 45(4): 287-295, 2011. (http://dx.doi.org/10.4275/KSLIS.2011.45.4.287〕 


\section{An Introduction: Unexpected Meeting with Mr. Ranganatha Yogeshwar}

In January 1970, I had my second chance of paying my visit to U. S. and European countries. When I got on the plane, I found an Indian man on my next seat. We began to talk just a few minutes, and he said, "So, you are a librarian in Japan, you may know my father's name." I was surprised and thought he was the son of Dr. Ranganathan. However, I knew there were famous library science scholars in India, and if I guess wrong, it would be rude to him. I cordially asked him the name of his father. He replied, "Ranganathan." It was incredible to me to sit side by side in the airplane with the son of Dr. Ranganathan. I almost shouted, "Oh, your father is Padma Sri Shiyali Ramamrita Ranganathan!” It was his turn to surprise and said, "Why do you know my father's such a long name. My friends call me simply, 'Rang' and nobody knows my full name." I proudly replied, "Because of your father's great achievements, every one of us working in libraries knows his name!" Now, let me tell you how and why Dr. Ranganathan has been well known in Japan.

\section{How the Five Laws of Library Science Has Influenced Library Activities in Japan}

\subsection{Introduction of the Book into Japanese Library World}

It was in 1935, one of the library leaders, K. Takebayashi, published his 21 pages of translation of the Third Chapter of the Five Laws as the best book he has every read on library movement in the world for the Japanese Library Journal. In 1952, again he introduced each of the Five Laws in detail for a local library science periodical. Such efforts of Takebayashi encouraged instructors and students of library science.

\subsection{The Library Law in Japan}

In 1950, the Library Law was promulgated as the first library legislation in Japan. Before that, library matters were prescribed as the Royal Orders of the Emperor, and everyone had to follow them without discussion. The Library Law was drafted under strong influence of the Occupation 
Authorities that regarded the library as an indispensable institution to develop democracy in the after World War II Japan. It prescribes the objectives of the library, library services, staff members, their qualifications and training, library authorities, free of charge for using library materials, etc. It has worked as the guiding principle for developing libraries in Japan.

\subsection{Education and Training for Librarianship}

The Ministry of Education established a library school in 1921. Five years after the war, Keio University in Tokyo established Japan Library School under the strong auspices of American Army and the American Library Association. In order to fulfill the needs of trained librarians in the new situation, the Library Law allowed universities to open short training institutes for librarianship. These courses invited well-experienced librarians as instructors and they talked enthusiastically about the Five Laws as the fundamental philosophy of library science. Dr. Ranganathan's name and his achievements became famous among young, would-be librarians. Encouraged by the efforts of library leaders, young librarians began to study about Dr. Ranganathan's various achievements. One of the foci was the facet analysis and some others studied them from the viewpoints of library managements and education for librarianship.

\subsection{The Five Laws as Ground Water}

Brief explanations of the Five Laws were published in the textbooks, cyclopedias, and books of introductory nature of library science. Full translation of the Five Laws (Second Edition) was published in 1981 by the efforts of library science professors and a librarian. The present writer published its commentary in 2010. In this way, the Five Laws worked to nurture each librarian's way of thinking. For example, an active librarian has regarded the Fifth Law as his motto because of its high-toned expression and far-sighted horizons, and it worked as a source of energy to overcome various difficulties.

\subsection{After World War II Development of Library Services in Japan}

The Library Law offered the legislative foundation for libraries in Japan, and the Five Laws worked as a beacon light towards the goal. As the result of more than 60 years of continued efforts, people in Japan check more than 711,715,000 items out from 3,168 public libraries 
in a year. It is 5.6 items per population on average. The First Law has been on the way to materialize.

\section{What Philosophical Challenges Are for Japanese Libraries?}

The Library Law of 1950 has the objective of developing democracy in Japan. Therefore, nobody denied the philosophy officially. In reality, however, there were different ideas and situations that prevented the execution of the law.

\subsection{The Tradition of Preservation}

Before promulgating the Library Law, books in national and public libraries were the property of the governing authorities. Readers had to beg the privilege to read them. The librarian was the guardian of books representing the authority of the governing body. The Library Law introduced the concept of "Books for All." On the other hand, long continued concept of "Preservation" remained in the minds of many people. They admired time-honored objects and did not agree with the concept of "Books for All." Some of them said, "If one wants to read books, he should buy them. Public property should not be used for personal satisfaction." Others disregarded the new concept. The power of 'disregard' has been very strong, and spread its influence over everywhere.

\subsection{Public Institution vs. Privatization}

Despite the strong power of disregarding 'Books for All' concept, the general public showed their keen interests in public library services. The number of books lending out from the public libraries increased one per population in 1979 to 5.6 in 2010. Such great changes produced another reaction. Local authorities and assembly members began to regard that the sole role of libraries was 'lending books.' From their viewpoint, lending service is an unskilled work, and any government employee can manage a library without any professional knowledge and experiences, because it is a government agency.

Introduction of computers relieved library staff members from the hard work of circulation procedures. Librarians expected that the work force of circulation could develop reference service. Local governments have not only disregarded the plan but also reducing the number of staff 
members in libraries, because they are seeking 'Cheap Government.' In order to save the expenditure of the government, they introduced the 'privatization' to libraries. It is a plan of managing the public library by a private firm with contract. Citizens and librarians strongly opposed to the plan saying that such a change of policy is a violation of Freedom of Reading, hindering the development of well-organized reference service for the local community, and preventing the accumulation of knowledge and experiences of library service for developing better library services. In short, the public library should be maintained by the local government as an educational institution for all the residents, and it should not be done by profit-seeking private firms. It is an evasion of the responsibility of the local government for the taxpayers.

Even the Minister of Public Management declared that the privatization for educational institution was inadequate and local bodies should reconsider the situation, but local government authorities disregard the statement.

\subsection{Memory Oriented Education vs. Growing Individual Thinking}

In each school situation, the entrance examination for the next level schooling has given a strong pressure to each teacher. They have to teach knowledge in textbooks and let the pupils memorize them so that they can prepare for the entrance examination of the next level. It was a long continued tradition. There are many arguments to the situation, but are disregarded in reality.

In the OECD Reading Comprehension Test in 2000, Japanese pupils had poor grades, and the Ministry of Education regarded it as an important problem. It emphasizes the value of reading other than text- and drill-books. The pressure of entrance examination in each school might be stronger than the statement of the Ministry

\section{What Measures Do Libraries Take for Challenges?}

There are many reasons of various difficulties in Japanese libraries, but the one we are responsible is the paucity of information among local authorities. They do not have their own opinion of "What is the Library, and How should it be?" For developing the library service as a social institution, we have worked in the following measures. 


\subsection{Efforts of Japan Library Association}

(1) Appeal to the Society: The JLA provides information on libraries to the people who concerned with the policy making of libraries at every opportunity. They are the members of Ministry of Education, Science, Arts and Culture; the national and local assembly members; and the mass communication people. Since 2009, the JLA and the Friends of the Library Group cooperating with the National Assembly members to hold a meeting in the National Assembly Building for discussing about the present situation of libraries in Japan with the assemblymen and their secretaries.

(2) JLA Proposal to the Government on the Cultural Development of Books and Libraries: It emphasizes the importance of developing all the types of libraries. One particular feature of the proposal is the plan of establishing one public library in a secondary school district. At present, there are 11,000 secondary schools in Japan and when the proposal is materialized more than 10,000 public libraries of more than 800 square meters $(8,600 \mathrm{sq}$. $\mathrm{ft}$ ) building, 50,000 volumes of books and 3 fulltime professional librarians. Local people welcomed the plan, and we are working toward the goal gradually.

(3) Establishing an advanced qualification for librarians: The JLA established a Standard of Qualified Librarians in 2010. It intends to encourage librarians' personal efforts to develop themselves. Each candidate submits his or her efforts of studying at various JLA seminars, their own publications, contributions as the practitioners, and a thesis required by the JLA. The JLA examine and evaluate these documents, and grant the title of Professional Librarian Approved by the Japan Library Association to the one successfully fulfilled the requirements. Librarians have discussed this topic for long years. Finally reached a concrete plan in 2010, it was executed in 2011. The first candidates who granted the new title were 38. Each of them is expected to work as a mid-echelon library administrator.

\subsection{Efforts of Librarians}

(1) National Organization: Besides the Japan Library Association, each type of library has a national organization. Among them, from the standpoint of this seminar, the Association of the Study of Problems in Libraries is worth to mention. In 1955, public librarians organized the association, and in 1977, it published its monthly periodical, Libraries for All, by their own efforts 
without any interruption. It has been an important guidepost for practitioners, and has disseminated the similar message with the First Law.

(2) Efforts of Local Librarians: There are many enthusiastic librarians in local libraries, and they maintain library services to the users by their own efforts based on their own library philosophy. Developing better image of libraries among general public is entirely depends on their daily library services.

\subsection{Efforts of Citizens}

(1) The National Committee of Friends of Library Groups: After 1950, the Friends of Library Groups began to be established in many local cities. They discuss the present situation of their public library, collect information about the other libraries, and think about how their library should be from the viewpoints of citizens. In April 2004, they got together and formed a national organization. It works to develop library policies, and in 2009, they worked to hold a meeting with the national assembly members in the assembly building.

(2) Local Activity of Developing School Libraries: The School Library Law was promulgated in 1953, and it prescribes that the school library is essential to develop school education, and teacher librarian should be placed in each school. Such provisions were entirely disregarded by local committee of education. Moreover, the Ministry of Education did not always favorable to materialize the School Library Law. Local parents in a city in Osaka, who have devoted themselves for encouraging children's interests in reading, asked the local committee of education to develop school library services. They advocated strongly that a school library needs a full-time professional librarian, submitted their proposal every year to the city for 13 years, and finally the head of the committee of education and the mayor accepted their proposal. Taking it as a good example, the similar activities spread over in many localities and the number of school librarians is increasing year by year.

\section{The Need of Theoretical Foundation for These Activities}

The efforts of citizens and librarians are great. However, the enthusiasm should have a firm 
foundation to think. There might be many theories we have to learn, and Dr, Ranganathan's Five Laws is one of them.

After published my commentary in the last year, we organized a reading circle of my book. The circle members consist of 13 librarians having experiences of 15 to 35 years practical work. We met at the Japan Library Association once a month for one year and half period. The followings are what I learned from the meeting.

(1) There is a general trend that readers regard each Law as an independent principle.

(2) It means that the inter-relationship among the Five Laws and its total meaning as an entity are disregarded.

(3) It is because Dr. Ranganathan described his deep thoughts of the Five Laws into 26 condensed English words. Only a genius can do such a work, but most of the readers tend to rely on their superficial interpretation.

(4) In order to reach to the depth of the Five Laws, the comments of each law supplied by the original author is indispensable.

(5) To understand the comments, I devised the following illustration as the first step toward the goal. 


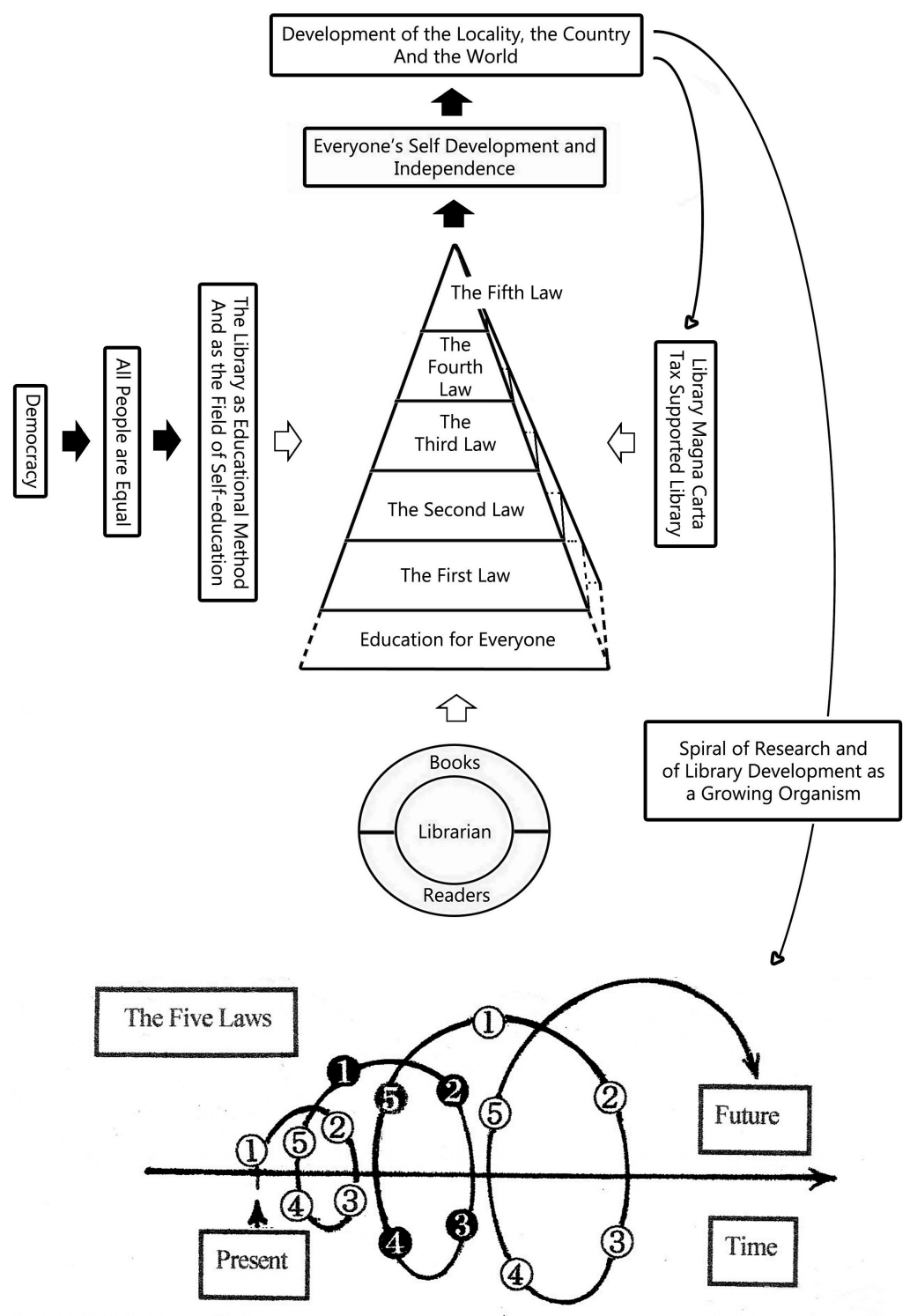

\section{Acknowledgements}

Thanks are due to Mr. Ranganatha Yogeshwar and my former professor, Dr. Martha Jane K. Zachert. Ranganatha Yogeshwar kindly answered my questions and sent valuable photos of his father for my book. Dr. Zachert encouraged me to write English papers and kindly edit my English since I was in her class in 1964. 